Магомедов К.М., Саркарова Н.А. Онтологический дискурс в исламской теологии и религии // Исламоведение. 2017. Т. 8, № 3. С. 95-112

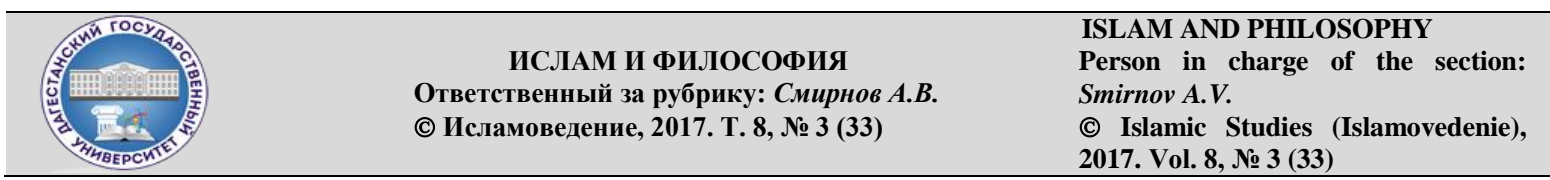

\title{
DOI: 10.21779/2077-8155-2017-8-3-95-112
}

УДК 297

\author{
K.М. Магомедов ${ }^{1}$ \\ Н.А. Саркарова ${ }^{2}$
}

\section{Содержание статьи}

Введение. Место

религиозной онтологии среди

других онтологий

Креационизм: философский, онтологический, физический и символический смыслы

Атомистическая концепция

бытия в исламе

Детерминизм и религия

Заключение

\section{Информация о статье}

Поступила в редакцию:

23.05.2017.

Передана на рецензию:

30.05.2017.

Получена рецензия:

29.06.2017.

Принята в номер:

25.08.2017.

\section{Онтологический дискурс в исламской теологии и религии}

\section{Дагестанский государственный университет, magomedov49@mail.ru}

В статье раскрываются некоторые составляющие исламской религиозной онтологии и проводятся параллели с другими религиозными онтологиями. Особое внимание обращается на формулу религиозного креационизма, выделяются его онтологический, физический, символический и другие смыслы. Перечисляются различные варианты креационизма и исследуется специфика их проявления в исламе. Особенно подробно исследуется онтологическая концепция вуджудитов о единстве Творца и творения, являющаяся своеобразной попыткой преодоления их дуализма в классическом исламе. Указывается также, что онтологическая символика ислама требует несколько иного рассмотрения диалектики бытия и небытия, чем это принято в науке, следующей парменидовской формуле «Бытие есть, а небытия нет». При этом делается попытка преодоления крайностей классической онтологии и нигитологии меонизма в понимании соотношения бытия и небытия. Подробно исследуется также атомистическая концепция в исламе, различные варианты понимания природы атомов и их пространственно-временной метрики. Отдельным параграфом анализируется принцип детерминизма в исламе. Автор показывает, что распространенная позиция, с которой любая религия рассматривается как вариант индетерминизма, не совсем полно отражает суть религиозного мировоззрения. Особенно, если иметь в виду, что существуют различные варианты некаузального или непричинного детерминизма, на которых построена вся онтологическая конструкция исламского мировоззрения.

Ключевые слова: онтология, религиозная онтология, ислам, креационизм, бытие $и$ небытие, атомистическая конщепчия, детерминизм $u$ индетерминизм, причинный $u$ непричинный детерминизм.

\footnotetext{
${ }^{1}$ Камиль Магомедович Магомедов - кандидат философских наук, доцент кафедры онтологии и теории познания ДГУ, orcid.org/0000-0002-1997-7503.

${ }^{2}$ Наила Ахедовна Саркарова - кандидат философских наук, доцент кафедры философии и социально-политических наук ДГУ.
} 


\section{DOI: 10.21779/2077-8155-2017-8-3-95-112}

UDC 297

\author{
K.M. Magomedov ${ }^{3}$ \\ N.A. Sarkarova ${ }^{4}$
}

\section{Content of the article}

Introduction. The place of religious ontology among other ontologies.

Creationism: philosophical, ontolo-logical, physical and symbolic meanings.

Atomistic concept of life in Islam.

Determinism and religion.

Conclusion.

\begin{abstract}
Information
about the article

Received: 23.05.2017.

Submitted for review:

30.05.2017.
\end{abstract}

Rewiew received: 29.06.2017.

Accepted for publication: 25.08.2017.

\section{The Ontological Discourse in Islamic Theology and Religion}

\section{Dagestan State University; magomedov49@mail.ru}

The article describes some of the components of Islamic religious ontology and its parallels with other religious ontologies. Special attention is paid to the formula of religious creationism. Ontological, physical, symbolic and other meanings thereof are discerned. Different versions of creationism are outlined and the specifics of their manifestations in Islam is investigated. Special attention is paid to the wujud ontological concept of the unity of Creator and creation, which can be viewed as an attempt to overcome their duality in classical Islam. It is also shown that the ontological symbols of Islam require a somewhat different consideration of the dialectics of being and nothingness, than is accepted in science following Parmenides' formula "Being exists, nothingness does not". The authors attempt to overcome the extremes of classical ontology and nigitology of meonizm in understanding the correlation between existence and nonexistence. The atomistic concept in Islam, different ways of understanding the nature of atoms and their spatial and temporal metrics are also considered. The principle of determinism in Islam is also discussed in a separate section. The authors demonstrate that the common standpoint from which any religion is considered as a variant of indeterminism, not quite fully reflects the essence of the religious worldview, especially if one bears in mind that there are different types of noncausal determinism, on which the whole ontological structure of the Islamic world is built.

Keywords: ontology, religious ontology, Islam, creationism, being and nothingness, atomistic concept, determinism and indeterminism, causal and noncausal determinism.

\section{Введение. Место религиозной онтологии среди других онтологий}

Онтологические концепции в различных формах мировоззрения существовали и будут существовать всегда. Ведь онтология - фундаменттальная часть любой картины мира и всякого мировоззрения. В этом выражается неустранимое стремление человека к априорным и целостным конструкциям мироздания и выяснению места человека в них. В соответствии с историческими типами мировоззрения можно выделить несколько видов таких онтологий: мифологическая, религиозная, философская, которые при всей своей взаимосвязи представляют собой самостоятельные модели осмысления бытия. Поэтому основные онтологические категории, такие, как бытие и небытие, материя и сознание, реальное и идеальное,

${ }^{3}$ Kamil Magomedovich Magomedov - Cand. Sc. (Philosophy), Associate Professor of the Department of Ontology and the Theory of Knowledge, DSU, orcid.org/0000-0002-1997-7503.

${ }^{4}$ Naila Akhedovna Sarkarova - Cand. Sc. (Philosophy), Associate Professor of the Department of Ontology and the Theory of Knowledge, DSU. 
Магомедов К.М., Саркарова Н.А. Онтологический дискурс в исламской теологии и религии // Исламоведение. 2017. Т. 8, № 3. С. 95-112

движение, пространство и время, детерминизм и некоторые другие, начали формироваться уже в мифологическом мировоззрении. В религии этот процесс интенсивно продолжался, и наконец современный статус самостоятельной сферы знания онтология получила в философии.

Цель настоящей статьи - осмыслить онтологическую тематику и проблематику в исламе, выявить общее и особенное в сравнении с христианскими, иудейскими и иными онтологиями. Данная задача представляется важной, поскольку выявление подлинного своеобразия исламского мировоззрения в условиях мультикультурализма невозможно без подведения под его основу онтологического каркаса. Что бы мы ни говорили о «коперниковском» перевороте И. Канта, положившем конец традиции выведения всего философского знания из онтологии, очевидно, что она является основой, на которой строится целостное здание всякого мировоззрения.

Исламская онтология, с одной стороны, соответствует всем признакам религиозной онтологии в целом; с другой - имеет отличительные особенности. Вот некоторые из общих черт религиозной онтологии:

- безапелляционность в претензиях на истину. Не меняет существа дела так называемая «инклюзивная» концепция истинности религии, озвученная акад. А.В. Смирновым в ряде публикаций, согласно которой не может считаться истинной религия, не признающая истинности другой религии [17]. Данная максима выражает суть практики межконфессиональных отношений в современный век культурного релятивизма. Но гносеологическая и онтологическая схематика принципиально не меняется; любая религия в своих онтологических и теологических допущениях видит единственно верное отражение Бога, бытия и человека. Отсюда возникают всевозможные препятствия догматического и организационного порядка на пути нахождения концептуального согласия, а реализация основных задач экуменического движения переносится на неопределенную перспективу;

- у всех религиозных доктрин онтологический концепт сформирован из мировоззренческих постулатов, имеющих прежде всего этический смысл. Поэтому любая онтологическая конструкция, каждое событие, вещь, процесс важны не сами по себе, а как выражения, символы взаимодействия двух вселенских сил добра и зла, имеющие глубокий нравственный мотив;

- религиозные онтологии наиболее влиятельны по сравнению с другими, более толерантными онтологиями. Вследствие многовековой индоктринации религиозные абстракции и символы стали важными составляющими окружающей действительности. Религиозные нарративы органично входят в культурно-языковые и ментальные основы существования того или иного народа [5; 6]. Это особенно верно для исламской религии с ее абсолютным монотеизмом, механизмы которой непосредственно вплетены в жизненную практику, общение и быт людей;

- она синкретична, поскольку онтологическая максима лежит в основании любого мировоззренческого конструкта. Это означает, что все другие формы духовного освоения мира: мифология, мораль, искусство, философия, наука постоянно наличествуют в этой онтологической схеме;

- символичность и метафоричность онтологических постулатов. Они чрезвычайно редко соответствуют реальным материальным или духовным процессам. Поэтому их буквальное и «прямое» чтение не предполагается, так как в них вкладывается самый различный символический и метафорический смысл;

- Бог абсолютен и наличествует во всем. Он являет собой форму всеприсутствия. Им наполнено все бытие, материальное и духовное, реальное и виртуальное, актуальное и потенциальное. Он одновременно во всем и при этом ни в чем конкретно не воплощается полностью. 
Отсюда вытекает одно важное онтологическое обстоятельство. Бога вообще нельзя позитивно определить через перечисление признаков и атрибутизацию; его можно понять только отрицательно - через термины отсутствия: недостижимый, непостижимый, необъятный, нематериальный, неявленный. Поэтому, согласно апофатическому богословию, Он не «уподоблен» чему-либо, ни в чем он не обнаруживает своей божественной сути. Даже основной способ определения понятий, принятый в логике - через подведение определяемого понятия под более общую категорию - не подходит для этого, поскольку Бог вне всякой бытийной метрики, и потому более широкого понятия, с которым его можно сравнить, просто не существует.

Таким образом, даже логика постижения и определения Бога противоречит рациональным механизмам человеческого постижения мира. С одной стороны, Его невозможно исчерпывающе постигнуть через положительную атрибутизацию, с другой стороны, нам всем хорошо известно логическое правило, согласно которому определение не должно состоять только из отрицательных терминов; хотя бы один признак должен быть положительным термином.

\section{Креационизм: философский, онтологический, физический и символический смыслы}

Креационизм - (от лат. creatio - созидание) - это учение, рассматривающее возникновение мира и человека как результат созидательной деятельности Бога, творца (а не результат эволюционного изменения) [3, с. 467].

Конечно, это определение правильное, но далеко недостаточное, поскольку оно не позволяет раскрыть глубинную и символическую суть божественного творения. Без добавления к концу данной формулировки слов «из ничего» теряется весь смысл религиозного креационизма, лежащего в основе иудейского, христианского и исламского мировоззрения, представляющего собой абсолютный монотеизм. Ведь творить можно и из некой предварительно существующей субстанции, подобно архитектору или художнику. Поэтому именно в творении «из ничего» проявляется вся мощь символики божественного всемогущества. Для творения из чего-то такого всемогущества и не требуется. Логика символического видения мира в монотеистических верованиях заключается именно в творении из ничего, вопреки физической метрике, построенной на известных законах «сохранения», суть которых сводится к утверждению невозможности подобного творения. Ислам в этом отношении, нами выделен особо, поскольку он являет собой абсолютный монотеизм, без всяких реальных и виртуальных составляющих, предшествующих акту божественного творчества.

Религиозный креационизм существует в самых разных вариантах:

- буквалистский или младоземельный креационизм, настаивающий на буквальном следовании Книге Бытия Ветхого Завета, согласно которой мир был создан в точности так, как там написано - за 6 дней и в строгой последовательности, и происходило это около 6000 - 7500 лет назад;

- метафорический или староземельный креационизм, согласно которому библейские «шесть дней творения» - это метафора, адаптированная к уровню развития людей того времени. На самом же деле творение - это длительный процесс, и одному «дню творения» соответствуют многие миллионы лет. И слово день в древнееврейском языке означает не только сутки, но и неопределённый отрезок времени;

- креационизм разрыва: Земля была сотворена задолго до первого дня творения и либо пребывала в «безвидном и пустом» виде те самые 4,6 млрд лет, о которых говорят научные данные, либо была опустошена Богом для нового сотворения. 
Магомедов К.М., Саркарова Н.А. Онтологический дискурс в исламской теологии и религии // Исламоведение. 2017. Т. 8, № 3. С. 95-112

Только после этого хронологического разрыва творение было возобновлено - Бог придал Земле современный вид и создал жизнь, как это было описано в Книге бытия, за шесть дней творения;

- креационизм постепенного творения, согласно которому Бог непрерывно направляет процесс природного и биологического развития. Представители данного направления признают геологические и астрофизические научные данные, кроме эволюционной теории и процесса видообразования через механизмы естественного отбора;

- теистический эволюиионизм (эволюционный креационизм), который признаёт теорию эволюции, однако утверждает, что эволюция является орудием Бога-Творца в осуществлении его замысла. Этот вариант креационизма хорошо был изложен в работах знаменитого Тейяра де Шардена и достаточно распространен среди современных религиозных философов. Например, как отмечает Андрей Кураев, в православии нет ни текстуального, ни доктринального основания для отторжения эволюционизма. Спокойное отношение к эволюционизму - это традиция православного академического богословия. Мнения и методы аргументации радикальных креационистов нельзя принять потому, что они произвольно и необъективно обращаются с научными данными, чем вызывают справедливые нарекания у людей, чья деятельность профессионально связана с наукой. «И здесь велика опасность того, что биолог, прочитав задиристую креационистскую книжку, слово халтура отнесет ко всему христианству как таковому». Он также считает, что «...неприемлемость для православного мышления идеи эволюции может быть доказана только в том случае, если будет разъяснено: каким образом допущение сменяемости поколений животных в мире до человека и вне эдема может ущерблять сознательность участия христианина в спасительных церковных Таинствах» [7].

Необходимо отметить, что в исламе нет подробного описания самого акта божественного творения мира и, тем более нет определенной оценки какого-то из перечисленных вариантов креационизма.

Обобщая все многообразие подходов к этому вопросу, можно сказать, что концепция креационизма существует в двух основных вариантах. Согласно первому, было одно творение всего бытия, в котором уже «предзаложено» все бесконечное многообразие его видов и состояний. Другой вариант теистического креационизма утверждает непрерывный и вечный процесс божественного творчества в духе окказионализма. Поэтому выраженный символическим языком шестидневный процесс творения мира на самом деле означает перманентный процесс созидания и вечного обновления мира.

Почему-то считается, что для последовательного теизма второй вариант творения предпочтительнее. Первая же позиция, по форме напоминающая деистическую формулу, согласно которой Бог только сотворил мир и запустил его основные механизмы, а затем уже не вмешивается в ход природных и социальных процессов, считается неприемлемой для религии. Думается, отождествление первого варианта творения с деистической формулой не совсем оправдано.

Обе формулы творения одинаково теистичны по своей сути, поскольку предполагается, что все многообразие бытия являет собой исключительный результат божественного творчества. Поэтому религиозная истина, наверное, заключается в обоих вариантах; с одной стороны, состоялся единовременный акт творения основных сфер бытия и человека, описанный в Ветхом завете, а также в Коране, хотя и не с такой подробностью. Назовем его процессом творения родовидового многообразия мира. С другой же стороны, осуществляется непрерывно и бесконечно происходящий процесс умножения этого мира через механизм постоянного творения. 
Иначе, как объяснить тот факт, что в первой и второй главах Книги Бытия, где раскрываются механизм и последовательность божественного творения мира и человека, даются две различные версии? В первой главе нет ни Адама, ни Евы, нет вообще указания на что-либо, позволяющее конкретизировать личности первых людей и их пол: единственное, что можно умозаключить из текста, так это то, что их было не менее двух, поскольку Всевышний говорит о них в местоимении «они». Во второй же главе появляются Адам и вся известная мифологема сотворения женщины, воспринятая впоследствии и исламом. Выходов из этого логического тупика всего два: или признать факт наличия противоречия в священном тексте Библии, на что религия и теология, наверное, не пойдут, или признать факт наличия в онтологической символике двух творений, или двух этапов творения, о которых мы говорили выше.

Креационизм может принимать самые разные мифологические формы, но их суть одна - признание принципиального различия между Творцом и творением, их неустранимый метафизический дуализм. Последний особенно усиливается и приобретает абсолютные формы в исламе. Если в иудаизме и христианстве этот дуализм в какой-то мере «смягчен» тринитарной символикой боговоплощения в Отца и Сына, а также механизмом творения человека по образу и подобию Бога, то ислам предполагает нетождественность и абсолютное разделение Творца и творения. Поэтому всякое боговоплощение рассматривается как атрибутизация Аллаха и придание Ему сотоварищей.

Считается также, что суфийская онтологическая символика преодолевает этот метафизический дуализм Творца и творения, что часто служит основанием для выведения его за пределы исламского мировоззрения. Это представляется не совсем справедливым.

Необходимо отметить, что в суфизме эта формула креационизма сохраняется, но происходят существенные изменения в понимании диалектики Творца и творения. Особенно это очевидно в учении вуджудитов об абсолютном единстве всего сущего в Боге. Он, с одной стороны, выражает «чистое бытие», с другой одновременно являет собой единство в многообразии через множество отдельных форм конкретного бытия.

Таким образом, наряду с формулой теологического монизма «Нет Бога, кроме Аллаха» устанавливается и другая формула «Нет бытия, кроме Аллаха». А на место теологического монизма традиционного ислама, отрицающего всякую множественность и атрибутивность Бога, ставится онтологический монизм, по которому единосущность Творца проявляется в множественности конкретных творений.

Как отмечают исследователи суфизма, привычный религиозный монотеизм в вуджудизме преобразуется в «моноонтизм», или «онтический монизм», утверждающий единство всего в Боге и через Бога [21, с. 169-176].

В религиоведении эта позиция вуджудитов получила название «манифестационизм» (от лат. manifestare - проявлять, проявляться). В отличие от классического креационизма, манифестационизм отказывается рассматривать творение как акт создания какой-то одной сущностью принципиально другой вещи, отличной от нее самой. Это в полной мере относится и к Богу. Поэтому бытие, согласно их разумению, являет собой продолжение и обнаружение Бога, развертывание Его качеств, поскольку нет Творца без творимого. Следовательно, нет в отдельности ни Творца, ни творения, они сущностно и содержательно неразделимы.

Сказанное, конечно, не означает абсолютного тождества Творца и творения, равенства между проявленным и непроявленным бытием, между Богом и миром. 
Магомедов К.М., Саркарова Н.А. Онтологический дискурс в исламской теологии и религии // Исламоведение. 2017. Т. 8, № 3. С. 95-112

Между ними сохраняется целая пропасть и иерархия. Но сущность манифестационизма заключается в устранении отмеченного выше дуализма Творца и творения в креационизме и в утверждении принципиального единства мира и его причины.

Манифестационизм характерен для всей мифологии, западной и восточной, для многих направлений индийской и китайской философии: индуизма, буддизма, конфуцианства. Из направлений исламской философии эта черта, пожалуй, характерна только для суфизма, особенно для ибн-Араби.

Когда говорим об абсолютном единстве всего сущего в Боге у вуджудитов, то сразу вспоминается формула всеединства у В. Соловьева. Но их отождествлять нельзя, и вот почему.

Во-первых, у великого русского религиозного философа речь идет именно о всеединстве, предполагающем не только единство Бога и бытия, но и антропологическое единство Бога и человека, воплощенного в Отца и Сына и выраженного им в концепции Богочеловека и Богочеловечества, что категорически не соответствует канонам ислама, о чем мы говорили в ряде статей ${ }^{5}$.

Во-вторых, речь у В. Соловьева идет также о гносеологическом единстве, предполагающем объединение всех возможных форм постижения Бога и мира: науки, религии, искусства, чувственного и логического, рационального и иррационального, эмпирического и теоретического познания; о гармонии веры и разума, веры и опыта.

В этом аспекте его концепция всеединства неизмеримо шире раскрывает содержание взаимодействия Творца и творений, чем это выражено в позиции вуджудитов, у которых, пожалуй, речь идет только об онтологическом единстве.

В-третьих, всеединство у Соловьева - это гармония всех частей Вселенной через принадлежность к абсолютному всеединству - Богу. Согласно же исламу, говорить о божественном единстве - это значит предполагать наличие у Бога конкретных признаков и атрибутов, что также есть серьезное нарушение канонов веры. Это естественно, поскольку любое единство - это «единство чего-то», какихто частей.

В этой связи необходимо заметить, что когда речь идет о суфизме и вуджудитах, то имеется в виду не единение Бога и бытия, Творца, творения и человека, а приближение к Нему. Хотя физический смысл терминов единения и приближения имеет общую основу, поскольку оба они имеют одинаковую пространственно-временную метрику, но символический, метафизический смысл процессов единения и приближения существенно отличается. Согласно таухиду (единобожию), Бог не обладает телесностью, не описывается в категориях времени, пространства, количества, качества [16, с. 5].

Как отмечает Чжун Сечжин, по общеисламской традиции суфизм называется термином тасаввуф, что в переводе с арабского означает «познавать», «постигать». То есть человек должен пытаться познать и понять Бога, он может приближаться к Всевышнему. Речь, разумеется, идет о духовном приближении [23, с.188]. Так и только так следует понимать суфийские символы единения, растворения человека в Боге.

В суфизме выделяют четыре ступени такого приближения к Богу:

- шариат - начальная образовательная и воспитательная система, обязательная для всех верующих, предполагающая внешнее знакомство с текстами Корана;

\footnotetext{
${ }^{5}$ Магомедов К.М. О степени богообразности и богоподобия в рациональной теологии // Исламоведение. - 2014. - № 4. - С. 58-65; Магомедов К.М. Проблема субъекта в исламской теологии // Исламоведение. - 2015. - № 2. - С. 77-85 и др.
} 
- тарикат - не обязательный для всех верующих. Он необходим для тех, кто выбрал путь внутреннего совершенствования, где постигается глубинный сакральный смысл Корана;

- хакикат - уровень высшего совершенствования, на котором открывается истина и постигается именно первоначальный смысл Корана, данный Всевышним самому Пророку;

- маарифат, когда достигается понимание Всевышнего не только разумом, но и сердцем. Носители этого уровня - шейхи, под руководством которых другими людьми постигается божественная истина, через которых божественная благодать передается остальным верующим.

В-четвертых, согласно христианству, наличие в мире, сотворенным всеблагим Богом, наряду с единством и гармонией противоположного начала, то есть хаоса, прямое следствие грехопадения. Поэтому вся логика и вектор онтологического развития мира в христианстве представляет собой процесс возвращения к этому первоначальному всеединству. И это при одновременном росте его многообразия.

Как мы знаем, исламское мировоззрение несколько по-другому представляет логику онтологического и антропологического развития: да, такой грех непослушания имел место в истории, но всепрощающий Бог простил и это. Поэтому этим грехом не отягощено все последующее развитие человечества; любой человек рождается безгрешным, как ангел, и свои грехи «зарабатывает» только сам. Таким образом, получается, что по исламу это первоначальное онтологическое единство мира никогда и никем не нарушалось.

Символический божественный акт творения всего из ничего ставит совершенно по-новому проблему соотношения бытия и небытия. Ведь в философии и культуре господствовала онтологическая матрица мышления, озвученная Парменидом, согласно которой, «бытие есть, а небытия нет». Справедливости ради необходимо заметить, что мировоззренческая почва для подобного философского концепта была подготовлена самой религией, а именно Ветхим Заветом, где сценарий божественного творения мира и человека был озаглавлен как Книга Бытия. Символика же небытия не получила в ней соответствующей оценки своей фундаментальности. Получается, что, хотя Бог сотворил бытие из небытия, его как бы и нет. А раз нет, то нечего и изучать. И вся культура, особенно сциентистски организованная, стала развиваться по этой «парменидовской» модели. Даже наличие в философии термина «онтология» как учения о бытии подтверждало монополию этой версии.

Переломной для современной онтологии, в т. ч. для религиозной онтологии, стала работа А.Н. Чанышева «Трактат о небытии», написанный еще в 1962 г. и опубликованный только спустя почти сорок лет. Она начала продолжающуюся до настоящего времени дискуссию о соотношении бытия и небытия, позволившую совершенно по-новому взглянуть на категорию небытия в культуре и философии $[22$, с. 3-13; 3, с. 52-67; 8, с. 66-79; 9, с. 15-32] и другие работы.

Нельзя сказать, что категория небытия не исследовалась в классической философской онтологии. Нет, эта категория, начиная еще с Парменида, всегда входила в орбиту философского дискурса. Однако она прилагалась только к отдельным явлениям, выражая внутренний механизм их развития. Считалось, что бытие абсолютно, небытие относительно. Оно есть выражение временности, становления, происходящего внутри вечного и бесконечного бытия. Бытие - это субстанция, оно первично; небытие же - акциденция, оно вторично, обусловлено бытием, есть выражение хаоса, пустоты, видимости. Бытие - жизнь, добро, истина, а небытие - смерть, зло, ложь и безобразие. Поэтому онтологии, построенной на категориях «ничто», «небытие», не должно быть в принципе [9, с. 16]. 
В современной ситуации постмодернизма наметилась тенденция отказа от такой метафизики, сутью которой является онтология как учение о бытии. Возникли даже новые понятия, альтернативные категориям онтологии, построенные на культе небытия: меонизм (от греч. те-оn - не сущее) - вера в «ничто» [10]. Таким образом, онтология превращается в нигитологию, в учение о небытии [8, с. 25-26].

Основные содержательные установки нигитологии сводятся к следующим тезисам:

- небытие предшествует бытию и следует за ним; бытие же существует в форме нечто на основе небытия и в единстве с ним;

- следуя за Гегелем, небытие, проявляясь в форме ничто, изначально неопределенно и потенциально. Из него естественно образование многообразных форм бытия;

- небытие выступает условием и ограничителем бытия [19, с. 57]

Мы не будем отстаивать крайности онтологии как учения о бытии и нигитологии как учения о небытии. Наверное, эти категории одинаково справедливо отражают различные стороны самого существования: бытие со стороны его устойчивости и закономерности, а небытие - изменчивости и случайности, стохастичности. Кстати, первая сторона бытия была хорошо разработана классической наукой, философией и диалектикой; а вторая - постмодернизмом, постнеклассической наукой и синергетикой.

Мы привели некоторые материалы этой жаркой философской дискуссии о диалектике бытия и небытия только с одной целью. Сказанное по поводу необходимости достойной оценки в науке, культуре и философии категории небытия позволяет увидеть новые глубинные смыслы в формуле религиозного креационизма, имеющего такую же метрику творения бытия из небытия. Скажем откровенно: после этого формула религиозного креационизма не представляется такой странной, ненаучной, антидетерминистской и нарушающей все варианты физических законов сохранения.

Иначе нам будут непонятны противоположные векторы оценок креационизма, означающего творение Богом всего из небытия. Ведь не секрет, что, с одной стороны, теология с ее базовой онтологической конструкцией креационизма в мире и у нас в России с недавнего времени объявлена научной дисциплиной со всеми вытекающими из этого следствиями. С другой стороны, наука в своей основе не приемлет креационизма. Поэтому Парламентская ассамблея Совета Европы (ПАСЕ), членом которой является и Россия (хотя она на время приостановила это свое членство), в резолюции № 1580 от 4 октября 2007 г. под названием «Опасность креационизма для образования» высказала обеспокоенность человечества последствиями распространения идей креационизма в рамках образовательных систем, и тем, что он может стать реальной угрозой правам человека, имеющим для Совета Европы первостепенное значение. Поэтому в резолюции подчеркивается недопустимость подмены науки верой и ложность утверждений креационистов о научности их учения.

Одним из вариантов понимания проблемы ex nibilo (из ничего), как нам представляется, является размежевание понятий сущего (мавжуд) и бытия, а также несущего (ма'дум) и небытия, осуществленное мутазилитами. Несущее, или ма'дум, означает не просто отсутствие бытия, что являет собой небытие, а вещь до своего возникновения, до ее перехода в состояние существования. Здесь онтологический статус несущего ясен: оно означает не принципиальное отсутствие бытия, а только отсутствие в вещной и актуальной форме. В потенциальной же форме, в божественном разуме оно существует. Как отмечает И.Р. Насыров в своей недавней добротной статье, мутазилитская концепция ма'дум в теологическом и

ИСЛАМОВЕДЕНИЕ. 2017. № 3


онтологическом плане служила цели обеспечения непротиворечивого понимания творения вещей в противовес учению о творении Богом всего из ничего. Для такого непротиворечивого объяснения божественного творения мутазилиты сочли необходимым трактовать его как перевод Богом вещей из одного онтологического статуса в другой - из ноуменального бытия в феноменальное, если следовать логике кантовского разделения бытия.

Таким образом, вещи могут существовать в двух онтологических модусах: 1) как ма'думы; 2) как вещи феноменального мира, обладающие актуальным существованием. Следовательно, ма’дум не есть абсолютное «ничто», а является способом наличия или модусом вещи в умопостигаемом (интеллигибельном) состоянии до ее перехода в состояние реального существования. С этой точки зрения небытие не является абсолютным отсутствием чего-либо, а являет собой пространство потенциального сущего [15, с. 58].

Правда, вызывает возражение сформулированный им тезис об отсутствии в Коране положения creation ex nihilo. Может быть, в тексте такого положения действительно нет, но данная смысловая максима подразумевается в соответствии с духом исламского абсолютного монотеизма. И оно имеет важнейшее мировоззренческое и методологическое значение, поскольку допущение чего-либо наряду с Богом предполагает отход от этого монотеизма в сторону деизма, тем более, что нам для восприятия даны исключительно коранические переводы смыслов, а не сами тексты.

\section{Атомистическая концепция бытия в исламе}

Сама атомистическая концепция всегда находилась в сфере интересов различных философских школ ислама, особенно всех вариантов калама. Причем диапазон различных версий, присутствующих в исламской философии, широко варьируется от крайнего финитизма до афинитизма, признания и отрицания пределов делимости в элементной структуре мира. И, что примечательно, во всех случаях это используется в качестве доказательства божественного всемогущества.

С одной стороны, отсутствие каких бы то ни было пределов, как атомистических, так и всяких иных, - это естественное проявление бесконечного и всеобъемлющего могущества Бога. Поэтому «многие мутакаллимы утверждали, что “атомы” обладают бесконечной делимостью» [18].

С другой стороны, Всевышний может опять-таки по логике своего всемогущества остановить всякое бесконечное деление тела на составляющие частицы. Например, стих в Коране, в котором говорится о Божьем исчислении счетом всякой вещи [4, 72:28], понимается так, будто отсюда следует невозможность бесконечного деления тела, ибо только конечное можно исчислять и охватить.

Во-первых, здесь чувствуется сильное влияние Аристотеля в исламской онтологии. Как известно, Стагирит в своем трактате «О возникновении и уничтожении» указывал, что деление до бесконечности превращает тела, а вместе с ними и Вселенную, в призрачную пыль, туманность и мираж. Следовательно, должен быть предел этому бесконечному делению. Отсюда следует, что деление тела должно быть приостановлено в каком-то пункте. Частицы, полученные таким образом, не могут быть телами, ибо «неверно, чтобы существовали неделимые тела или величины». С другой стороны, они не могут быть непротяженными точками, поскольку «бессмысленно, чтобы из тех слагаемых, которые сами не являются величинами, составлялась бы величина» [1, с. 386].

Как отмечает Тауфик Ибрагим, «мутакаллимы-атомисты фактически различали физическую и математическую делимость, останавливая процесс деления на «наимень-ших телах» (акалль аль-аджсам), которые соответствуют 
«первотельцам»/атомам Де-мокрита и Эпикура, а еще в большей мере «минимальной линии» пифагорейцев и платоников. При этом он опирается на Ашари, который утверждает: «Части, ...делятся вплоть до двух частей, после чего, если захочешь делить их дальше, то деление их уни-чтожит; если попробуешь вообразить одну из них, то не обнаружишь ее в воображении (вахм); когда же пожелаешь различить их воображением или иначе, то обнаружишь не что иное как их исчезновение» [2, с. 317].

Конечно, как отмечается в философской литературе, было бы ошибкой рассматривать мутазилитский и ашаритский атомизм как прямой и непосредственный фундамент исламской теологии с еe окказионализмом, креационизмом и индетерминизмом [20, с. 142-154]. В европейской (западной) литературе такой стереотип сложился преимущественно под влиянием сочинения знаменитого критика калама Маймонида [13].

Исследователи атомистической концепции мутакалимов часто задумываются над следующим парадоксом: как вообще исламское богословие с его абсолютным монотеизмом, креационизмом и индетерминизмом могло использовать в своих аргументациях атомистические концепции Демокрита, Левкиппа и Эпикура, имеющие материалистическую и атеистическую направленность? По мнению многих исследователей, ответ напрашивается один: средневековые исламские богословы по объективным обстоятельствам не могли хорошо и глубоко знать античную философскую культуру. Как отмечает А.О. Маковельский, «если бы мусульманские богословы во главе с Ашари знали подлинное учение Демокрита, они с ужасом отвернулись бы от него» [11, с. 113].

Нам же представляется, что причина несколько в другом. Как известно, во времена А.О Маковельского жесткая марксистско-ленинско-сталинская историкофилософская методология на основе принципа партийности требовала однозначной оценки всех концепций как материалистических или идеалистических и соответствующей их интерпретации, согласно которой любой материализм, даже такой примитивный, как у древних атомистов, - это путь к атеизму. Очевидно, что однозначное отнесение древних атомистов к материалистам в принципе ничем не оправдано, поскольку для них атомы - это, скорее, умозрительные реальности, те же идеи-эйдосы Платона, которые можно постигнуть только рационально. Это, вопервых. Во-вторых, проведение аналогии и параллелей типа «материализм означает атеизм, а идеализм - теизм» также не совсем корректно, поскольку они представляют собой различные векторы и концепты осмысления бытия.

В связи со сказанным напрашивается одна мысль, достаточно парадоксальная для всей методологии историко-философского и научного анализа. Существующая в науке и философии практика однозначной оценки культурно-исторических реалий, особенно в позитивном или отрицательном векторе, достаточно груба и непоследовательна. Это касается всего и даже анализируемой нами атомистической концепции, которая всегда рассматривается как исключительно положительная. Конечно, никто не ставит под сомнение эвристическое содержание атомистической ориентации познавательного интереса вообще. Но атомистическая идея о неделимых «первокирпичиках» бытия оказалась впоследствии одним из самых «долгоиграющих» заблуждений человечества. Пожалуй, так долго человечество (почти 2,5 тысячелетия) не заблуждалось ни в чем (неделим, а следовательно, нечего и пытаться думать по-другому) пока в XX столетии не был открыт электрон. Так что пора ставить вопрос об историческом «вреде», нанесенном науке данной теорией. Хотя история не приемлет сослагательного наклонения типа «что бы было, если бы...», можно сказать следующее: если бы не было в истории этой в принципе неверной теории, вполне возможно, что квантовая теория возникла бы не в XX веке, 
a несколько раньше. По крайней мере, такие мысли возникают при оценке атомистической концепции древних мыслителей.

Особый исследовательский интерес вызывает понимание некоторыми мутакаллимами наряду с атомами пустоты. Как отмечает Маймонид, для утверждения движения атомов необходимо допустить самостоятельное существование пустоты [13, с. 419]. В этом также чувствуется влияние на исламскую онтологию аристотелевской философии. Но многие последователи калама пошли по пути отрицания пустоты между атомами, о чем подробно говорит Тауфик Ибрагим. Согласно его мнению, для многих мутакаллимов-финитистов атомы не существуют вне тела, поэтому для обоснования возможности их движения, соединения и разъединения нет необходимости в пустоте между атомами. Пустота возможна только между телами, но не между атомами [20, с. 143].

Конечно, было бы большой натяжкой утверждать, что философы-каламисты еще тогда предвидели становление неклассической науки и релятивистской концепции пространства и времени, опровергнувшей их субстанциональность, но выводы напрашиваются определенные. Главный из них сводится к следующему утверждению: отрицать пустоту между атомами, вопреки здравому смыслу и принципу наглядности, без которого было немыслимо понимание движения, - это свидетельство высокой философской культуры мутакаллимов. Это также доказательство наличия у них серьезных навыков абстрагирования от чувственного бытия, трансцендентных способностей, искусства понимания того, что вовсе не укладывается в рамки обыденного, привычного и повседневного сознания.

Необходимо заметить, что вообще всякая апофатическая культура, построенная на отрицании наличия чего-то в бытии, плохо укладывалась в метрику любого теизма, поскольку она при определенных условиях может привести к возникновению сомнений во всемогуществе и абсолютности Бога. Поэтому более приемлемой для абсолютного монотеизма является аристотелевская концепция атомов и пустоты между ними. Если под этим углом зрения оценивать взгляды представителей калама об атомах и пустоте, то они нам представляются исторически прогрессивными.

Не все мутакаллимы были согласны с этими постулатами и разделяли атомистическую онтологическую концепцию бытия, например, так называемая ханафитско-матуридитская школа калама, захириты, ханбалиты и другие богословские школы [25].

Еще больший интерес вызывают рассуждения мутакаллимов относительно пространственной характеристики атомов. Последние, согласно их учению, лишены всякой телесности, но при этом имеют пространственную метрику. Это естественно, поскольку без этого атом как субстанция всего бытия не может состояться. В качестве субстанции мира он не может не обладать определенным объемом, величиной [2, с. 318].

Как тут не возникнуть определенным аналогиям из истории современной физики о вещественных и невещественных форм материи и критериях их различения? Ведь к изучению существования материи, не обладающей протяженностью, к которой неприменимо классическое (вещественное) ее понимание, физика пришла совсем недавно, после открытия корпускулярноволнового дуализма. Получается, средневековой исламской философией эта идея была гениально предугадана, пусть в интуитивной форме.

\section{Детерминизм и религия}

Устоявшейся в религиоведческой литературе является установка, согласно которой одно из принципиальных отличий науки и религии актуализируется через 
принцип детерминизма: наука формирует свои постулаты на основе закономерных причинно-следственных зависимостей; религия же в своей основе есть форма индетерминизма, отрицания детерминизма. Поэтому считается, что подлинная вера опирается на всемогущество Бога и принципиально не должна быть построенной на детерминизме, поскольку это обрекает человека на пассивность, отказ от ответственности за свои деяния. С этой позиции детерминизм - важнейший фактор одурманивания людей и народов.

Нам представляется, в этом проявляется недостаточный уровень философской культуры верующих и теологии в целом, проявляющийся в неправильном понимании самого детерминизма, когда он сводится только к физическому или каузальному детерминизму, абсолютизирующему объективные механизмы причинно-следственных взаимодействий. При этом не учитывается то обстоятельство, что существуют еще непричинные или некаузальные виды детерминации, о чем мы говорили в ряде статей ${ }^{6}$.

Каузальный детерминизм, очень хорошо раскрытый в философии и науке, связан с различными механизмами переноса вещества, энергии и информации от причины к следствию. Если ограничиться таким видом детерминизма, то, пожалуй, можно согласиться с тем, что религия есть форма индетерминизма. А относительно многочисленных форм некаузальной или непричинной детерминации, очевидно, что многие из них действуют и в религиозных концептах.

Во-первых, это касается психического детерминизма, в основе которого лежат различные ассоциативные механизмы, в которых действуют не каузальные, а смысловые совпадения. К.Г. Юнг на основе изучения многих сновидений и других явлений пришел к выводу о существовании известной синхроничности между психическими и жизненными процессами. Обоснованию этого самого синхронического детерминизма им были посвящены две работы «О синхроничности» (1951) и «Синхроничность: акаузальный объединяющий принцип» (1952).

Во-вторых, это функциональный детерминизм, раскрывающий всевозможные корреляционные зависимости. Примером такой зависимости являются парные философские категории: материя и форма, сущность и явление, форма и содержание и другие. Математика рассматривает только такие функциональные, а не каузальные зависимости.

В-третьих, это информационный детерминизм, который также нельзя однозначно отнести к каузальному детерминизму, поскольку информационные составляющие причинно-следственных отношений обладают известной независимостью от вещественно-энергетических процессов.

B-четвертых, это так называемый дефинитивный детерминизм, проявляющийся в диалектике общего и единичного, который встречается на каждом шагу. Например, когда одно понятие определяется через другое («Жучка есть собачка», «Круг - это фигура, получаемая вращением отрезка вокруг одного из концов»).

В-пятых, это телеологический или целевой детерминизм, согласно которому во многих процессах цель как закон предопределяет их протекание. Эта форма детерминации была известна еще со времен античности. Например, Аристотель в

${ }^{6}$ Магомедов К.M. О некоторых некаузальных формах детерминизма (статья первая) // Вестник Дагестанского государственного университета. - 2013. - Вып. 5. - С. 233-237; Магомедов К.М. О некоторых некаузальных формах детерминизма (статья вторая) // Вестник Дагестанского государственного университета. - 2014. - Вып. 5. - С. 206-214. 
своей классификации причин выше всех ставит целевую причину, которая является источником всех стремлений, реализующихся в развитии. Подобный подход мы встречаем у Лейбница, Шеллинга, Гегеля, в неотомизме, неовитализме. Нас здесь интересует телеология не в религиозно-философско-мировоззренческом смысле, а как действенный принцип, утвердившийся в науке и методологии науки.

Особый интерес к проблеме целевой детерминации связан с успехами современной космологии, с исследованиями некоторых неизвестных до сих пор характеристик Вселенной. Например, в 70-е годы XX в. был сформулирован антропный принцип, устанавливающий зависимость возникновения и существования человека от физических параметров Вселенной. Вселенная обладает такими свойствами, что в ней на определенном этапе обязательно должны были возникнуть жизнь и сознание. Пусть возникновение жизни - это результат невероятного стечения многочисленных обстоятельств, но, согласно этому принципу, в итоге жизнь не могла не возникнуть.

Сказанное доказывает, что не всякий целевой или телеологический подход к пониманию детерминизма означает уступку религии и мифологии. В современной науке он не раз доказывал право на объективность и методологическую полезность. Это, во-первых.

Во-вторых, отсюда следует, что не всякие телеологические представления следует оценивать как индетерминизм, о чем свидетельствует антропный принцип в астрофизике.

В-третьих, не всегда религиозные и теологические постулаты действуют в русле детерминизма, если под ним понимать не только объективную причинность, но и другие виды взаимного обусловливания явлений и процессов. Разве, скажем, первое или пятое доказательства бытия Бога у Фомы Аквинского, да и доказательные аргументы Ансельма Кентерберийского лежат за пределами функционального или целевого детерминизма? Да нет, они целиком построены на них.

Можно продолжить перечислять и другие виды непричинной детерминации процессов, но, пожалуй, достаточно. Не вызывает сомнений, что отмеченные виды детерминации на каждом шагу встречаются в процессах, составляющих предмет религиозной догматики и теологии, исламской в том числе.

Здесь мы еще раз убеждаемся в том, что различия между наукой и религией во многом были раздуты и преувеличены, что само по себе мешало раскрытию созидательной сущности этих важнейших форм постижения мира и человека.

Как мы видим, догматическое мышление, действующее по логике «или-или», противопоставляет два важнейших механизма - провиденциализм и детерминизм, относя первый к сфере религии, а второй - к науке. От этого не выигрывают ни сама наука, ни религия. Детерминизм - объяснительный принцип не только науки, но и теологии, особенно в современных условиях, когда она обрела научный статус. Правда, справедливости ради необходимо отметить, что эти два механизма в религиозном сознании и теологии неравнозначны, первенство божественного предопределения над детерминизмом - их общая черта. Господь обусловил существование всех вещей и процессов наличием в мире соответствующих причин и условий. И свободную волю Он также поставил не в стороне от детерминизма, а в самом ряду причинно-следственных связей.

Еще одним проявлением догматического понимания детерминизма является его противопоставление свободе человеческой воли. Особенно остро этот вопрос ставился в исламе в Средние века, хотя он и сейчас не утратил своей актуальности. Например, джабрииты проповедовали концепцию жесткого и абсолютного предопределения Аллахом всего еще до творения. Человек в такой жесткой 
детерминации не является исключением, поэтому он не обладает никакой самостоятельностью и свободой воли. С сожалением приходится отмечать, что такое понимание часто распространяется на весь современный ислам, где действуют исключительно механизмы предопределения. Поэтому исламское мировоззрение объявляется даже бессубъектным $[12,16]$.

Кадариты и их последователи среди мутазилитов, наоборот, считали, что всемогущество Бога распространяется только на природную детерминацию и не распространяется на человека, поэтому он обладает полной свободой воли. Аллах ставит верующих перед выбором, в противном случае непонятной будет логика наделения человека ответственностью за свои деяния.

Сама же концепция предопределения в исламской теологии существует в различных исторических формах:

- фаталистическое предопределение - в форме «абсолютного принуждения», как у джабриитов, о которых говорилось выше;

- предопределение в форме «умеренного принуждения», достаточно широко распространенное в теологии и философии ислама, признающее диалектику предопределения и свободы воли. Формулу такой позиции хорошо выразил средневековый мусульманский философ аль-Багдади: «справедливый суннит тот, кто избегает безусловного предопределения (аль-джабр) и свободы воли (аль-кадар)» [24, с. 144-155];

- предопределение как предвидение будущего через Логос, Божественный разум, не стесняющее человеческой свободы. Оно означает не форму принудительной детерминации, а деятельность через полноту божественного всезнания, через всеобъемлющее знание Бога.

С.Н. Чудинов выделяет четыре ступени в мусульманской детерминации через механизмы божественного предопределения:

а) божественное абсолютное всезнание;

б) предписание через письменную фиксацию божественного волеизъявления;

в) соизволение Всевышнего, которым охвачено все бытие в целом, а также каждая вещь и живое существо в отдельности;

г) сотворение, в сферу которого входят и все поступки человека [24].

\section{Заключение}

Во-первых, мы убеждаемся в том, что именно через постоянную включенность онтологической проблематики в теологический дискурс исламским мировоззрением приобретается должный теоретический статус и достаточный философский уровень.

Во-вторых, именно через онтологическую проблематику происходит сближение предметного поля науки и религии, этих двух важнейших векторов развития человеческого духа и постижения мира.

В-третьих, усиление межконфессионального взаимодействия в современных условиях происходит не только и не столько в сферах самой религиозной догматики, сколько в прикладных вопросах, к которым относятся онтологические проблемы.

\section{Литература}

1. Аристотель. Сочинения: в 4 т. Т. 3. - М.: Мысль, 1981.

2. Ащари. Макалят аль-ислямийин. - Висбаден, 1980.

3. Большой толковый словарь русского языка / сост. и гл. ред. С.А. Кузнецов. СПб.: Норинт, 1998. - 1536 с.

4. Коран / пер. с араб. акад. И.Ю. Крачковского. - М.: СП ИКПА, 1990.

5. Красиков В.И. Онтологии // Вопросы философии. - 2013. - № 9. - С. 43-51.

6. Красиков В.И. Озарение трансценденцией: в поисках Бога и себя. - М.: Директ-Медиа, 2014.

7. Кураев Андрей. Православие и эволюция // svitk.ru. 
8. Кутырев В.А. Крик о небытии // Вопросы философии. - 2007. - № 2. - С. 66-79.

9. Кутырев B.A. Оправдание бытия (явление нигитологии и его критика) // Вопросы философии. - 2000. - № 5. - С. 15-32.

10. Лосев А.Ф. Русская философия // Русская философия. Очерки по истории. Свердловск: Издательство УрГУ, 1991. - 132 с.

11. Маковельский А.O. Атомистика на Ближнем Востоке // Вопросы философии. - 1957. - № 3. - С. 111-118.

12. Можаровский B.B. Критика догматического мышления и анализ религиозно-ментальных оснований политики. - СПб.: ОВИЗО, 2002.

13. Моше бен Маймон (Маймонид). Путеводитель растерянных. - М., 2010.

14. Насыров И.Р. Формирование общего блока вопросов метафизики в каламе в IX-XII вв. // Исламоведение. - 2017. - Т. 8, № 1. - С. 54-69.

15. Ракитянский Н.M. Опыт концептуального анализа исламского менталитета в контексте политической психологии // www. Lawinrussia.ru/node/217241.

16. Сафави Сайид Салман. Практический мистицизм. - М.: Академический проект: Садра, 2013.

17. Смирнов А.В. Классический ислам и современный Дагестан: как можно сегодня прочитывать исламское наследие // Проблемы российского самосознания: историческая память народа. Материалы 12-й Всероссийской конференции. МоскваМахачкала, апрель 2015 г. - М.-Махачкала: Дельта-Пресс, 2015. - С. 43-54.

18. Смирнов А.В. Великий шейх суфизма. - М., 1993.

19. Солодухо Н.M. Отношение бытия и небытия как исходная философская проблема. Гуманитарные и социально-экономические проблемы // Вестник Казанского технологического университета им. А.Н. Туполева. - 1996. - № 3. - С. $55-59$.

20. Тауфик Ибрагим. Мусульманский атомизм как строгий финитизм // Вопросы философии. - 2014. - № 6. - С. 142-154.

21. Фролова E.A. Средневековая арабская философия: проблемы и решения. М.: Изд-во восточной литературы РАН, 1998. - 527 с.

22. Чанышев А.Н. Трактат о бытии // Вестник Московского университета. Сер. 7 Философия. -2000 . - № 2. - С. 3-13.

23. Чжун Сечжин. Общие религиозные аспекты мистицизма в суфийской традиции // Вопросы философии. - 2017. - № 2. - С. 186-194.

24. Чудинов С.Н. Фатализм мусульманского мировоззрения в преломлении террориста-смертника // Религиоведение. - 2009. - № 4. - С. 144-155.

25. Шигабутдин Марджани. Зрелая мудрость в разъяснении догматов анНасафи. - Казань, 2008.

\section{References}

1. Aristotel'. Sochineniya $v$ chetyrekh tomah [Writings in four volumes.]. - V. 3. Moscow. Mysl, 1981.

2. Ashari. Makalyat al'-islyamijin [Maqalat al-islamiyyin.]. - Visbaden, 1980.

3. Kagan M.S. Metamorfozy bytiya i nebytiya. K postanovke voprosa [Metamorphosis of Being and Nothingness. Question Formulation] Voprosy filosofii [Issues of Philosophy], - 2001. - № 6. - S. 52-67.

4. Koran. [Quran] Per. s arab. Akad. I.YU. Krachkovskogo. - Moscow. SP IKPA, 1990.

5. Krasikov V.I. Ontologii.[The Ontologies] Voprosy filosofii [Issues of Philosophy] 2013, № 9. - S. 43-51.

6. Krasikov V.I. Ozarenie transcendenciej: v poiskah Boga i sebya [The Revelation by the Transcendence: in Search of God and Oneself] Moscow. Direkt-Media, 2014. 
7. Kuraev Andrej. Pravoslavie i ehvolyuciya [Christianity and Evolution // svitk.ru. About-Rasch] URL svitk.ru.

8. Kutyrev V.A. Krik o nebytii [Cry for Nothingness] Voprosy filosofii [Issues of Philosophy]. - 2007. - № 2. - S. 66-79.

9. Kutyrev V.A. Opravdanie bytiya (yavlenie nigitologii i ego kritika) [Justification of Existence (the Phenomenon of Nigitology and Its Criticism)] Voprosy filosofii [Issues of Philosophy]. - 2000. - № 5. - S. 15-32.

10. Losev A.F. Russkaya filosofiya [Russian Philosophy]: Russkaya filosofiya. Ocherki po istorii [Russian Philosophy. Essays on History]. - Sverdlovsk: Izd-vo Ural'skogo universiteta, 1991. - S. 72-73.

11. Makovel'skij A.O. Atomistika na Blizhnem Vostoke [Atomistics in the Middle East] Voprosy filosofii [Issues of Philosophy]. - 1957. - № 3. - S. 111-118.

12. Mozharovskij V.V. Kritika dogmaticheskogo myshleniya $i$ analiz religioznomental'nyh osnovanij politiki. [Critique of Dogmatic Thinking and Analysis of ReligiousMental Foundations of Politics.] SPb: OVIZO, 2002.

13. Moshe ben Majmon (Majmonid). Putevoditel' rasteryannyh. [Guide for the Lost] Moscow, 2010.

14. Nasyrov I.R. Formirovanie obshchego bloka voprosov metafiziki v kalame v IXXII vv. [The Formation of a Pool of Metaphysics Questions in Kalam in the $9^{\text {th }}-12^{\text {th }}$ Centuries] Islamovedenie [Islamic Studies]. - 2017. - V. 8, № 1. - S. 54-69.

15. Rakityanskij N.M. Opyt konceptual'nogo analiza islamskogo mentaliteta $v$ kontekste politicheskoj psihologii [An Experience of Conceptual Analysis of Islamic Mentality in the Context of Political Psychology] URL: www. Lawinrussia.ru/node/217241.

16. Safavi Sajid Salman. Prakticheskij misticizm [Practical Mysticism]. - Moscow: Akademicheskij proekt: Sadra, 2013.

17. Smirnov A.V. Klassicheskij islam i sovremennyj Dagestan: kak mozhno segodnya prochityvat' islamskoe nasledie [Classical Islam and the Contemporary Dagestan: How May Islamic Heritage Be Interpreted Today] Problemy rossijskogo samosoznaniya: istoricheskaya pamyat' naroda. Materialy 12-j Vserossijskoj konferencii. [Problems of Russian Identity: Historical Memory of the People. Proceedings of the $12^{\text {th }}$ all-Russian Conference] Moscow-Mahachkala, aprel' 2015 g. - Moscow - Mahachkala: Del'ta-Press, 2015. - S. 43-54.

18. Smirnov A.V. Velikij shejh sufizma. [The Great Sheikh of Sufism] - Moscow, 1993.

19. Soloduho N.M. Otnoshenie bytiya i nebytiya kak iskhodnaya filosofskaya problema [The Relation of Being and Nothingness as the Basic Philosophical Problem] Gumanitarnye $i$ social'no-ehkonomicheskie problemy. Vestnik Kazanskogo tekhnologicheskogo universiteta im. A.N. Tupoleva 「Humanitarian and Socio-Economic Issues. Bulletin of Kazan Technological University. A.N. Tupolev]. - 1996. - № 3. - S. 5559.

20. Taufik Ibragim. Musul'manskij atomizm kak strogii finitizm 「Muslim Atomism as Rigorous Finitism] Voprosy filosofii [Issues of Philosophy]. - 2014, № 6 - S. 142-154.

21. Frolova E.A. Srednevekovaya arabskaya filosofiya: Problemy $i$ resheniva. [Medieval Arabic Philosophy: Problems and Solutions]. - Moscow: Izd-vo vostochnoj literatury RAN, 1998. - 527 s.

22. Chanyshev A.N. Traktat o bytii [A Treatise on the Genesis] Vestnik Moskovskogo universiteta. Ser.7 «Filosofiya» [Bulletin of Moscow University. Ser.7. Philosophyl. - 2000. - № 2. - S. 3-13.

23. Chzhun Sechzhin. Obshchie religioznye aspekty misticizma v sufijskoj tradicii [The General Religious Aspects of Mysticism in the Sufi Tradition] Voprosy filosofii [Issues of Philosophy]. - 2017. - № 2. - S. 186-194. 
24. Chudinov S.N. Fatalizm musul'manskogo mirovozzreniya v prelomlenii terroristasmertnika [The Fatalism of the Muslim Worldview through the Eyes of a Suicide Bomber] Religiovedenie [Religious Studies]. - 2009. - № 4. - S. 144-155.

25. Shigabutdin Mardzhani. Zrelaya mudrost' v raz"yasnenii dogmatov an-Nasafi [Mature Wisdom in the Interpretation of an-Nasafi Dogmas]. - Kazan, 2008.

\section{Критерии авторства}

$\begin{array}{lr}\text { Магомедов K.M. } & -\underset{\text { анализ и }}{\text { систематизация }} \\ \text { материалов. } & \text { имеющихся } \\ \text { Недактирование. } & \text { Научое }\end{array}$
редактирование.

Саркарова Н.A. - поиск и работа с источниками, в т. ч. по проблемам теологии.

Авторы в равных долях имеют отношение к написанию рукописи и одинаково несут ответственность за плагиат.

Конфликт интересов

Авторы заявляют об отсутствии конфликта интересов.

\section{Authors' Contributions}

Magomedov K. M. - analysis and systematization of the materials available. Academic editing.

Sarkarova N.A. - search for and working with sources, including those on the issues of theology.

The authors are equally relevant to the writing of the manuscript and equally bear the responsibility for plagiarism.

\section{Conflict of interest}

The authors declare no conflict of interest. 